10.53116/pgaflr.2017.2.3

\title{
The Status of e-Administration in Hungary - Are We on the Right Track?
}

\author{
Bernadett Veszprémi*
}

\begin{abstract}
* JUDr. Bernadett Veszprémi, PhD, Assistant Professor at the Department of Administrative Law at the Faculty of Law, University of Debrecen. (e-mail: veszpremi.bernadett@law.unideb.hu)
\end{abstract}

\begin{abstract}
The goal of this study is to define (or find out) where Hungary currently stands in the development of e-Administration solutions. The issue is more topical than ever, as infocommunications became an integral part of our daily lives, affecting both the private and public sectors, and changing our ways of working - thus, it requires our understanding. When it comes to the public sector, however, striking changes can only be achieved if the entire process of public administration is (or would be) changed. The goals are clear: work should be faster, as it would result in satisfied clients, cut costs and more efficient procedures. The question to ask now is where Hungary stands in this endeavour. Are we on the right track?
\end{abstract}

Keywords: e-Administration; e-Management; e-Communication; interoperability

\section{Introduction}

The European Union already realized back in the 1990s that it can only compete with Japan and the United States of America if it strives to create a knowledge society. Reaching this goal, however, requires being a leading force in electronic developments, as well. This, of course, does not just mean the development of new technologies, but also the training of people who can and want to use such innovations. Private sector enterprises have long come to understand the necessity of this transformation, hence their attempts to gradually change their marketing and ways of working. When it comes to the public sector, a different approach is necessary, where the regulation itself has to be studied in the first place, to understand the system and current state of e-Administration.

Concerning the regulation, it basically fulfils its role and meets the actual expectation. On the one hand, centralization (which already appears in numerous aspects of e-Administration) is required; on the other hand, making various functions and services available on the market to ensure the more efficient and complete service of clients is certainly a good direction. E-Administration requires standardization and central decisionmaking, due to the complexity of its technical background, to ensure the interoperability of its systems, and eventually to achieve its general availability.

The developments are already underway, and the organizational integration of regional-level state administration leads to the need of establishing permeability among the various specialized systems. At the same time, on the level of self-governments, the deployment of the ASP also serves the same goal of standardization and unification. The procedure thus started - we are now looking forward to its continuation. 
We must admit that Hungary is lagging a decade behind the EU when it comes to e-Administration: after all, while the EU took concrete steps to develop the strategy of e-Administration in the 1990s, the first initiatives in Hungary were only made at the beginning of the 2000s. We also could not meet the related deadlines of the EU, such as the eEurope 2005 or the CLPBS recommendations. The idea of using integrated, interoperable systems and services is good, but we should not forget that there are several countries which use such services for years now.

I can only hope that the next five years will bring substantial changes in this field; however, launching the new developments, along with their reconciliation and alignment to practical needs will not occur without problems - just like the elimination of the resistance against the new and unknown.

To be able to outline the current stance and the arc of development of Hungarian e-Administration, first we must define the concept itself. I find this very important to clarify, as international literature tends to specify it in a variety of ways. For example, e-government stands for a different concept in English-speaking countries than in Germany or other territories. In a wider sense, government and governance comprise all agents and activities of the executive power; however, the Hungarian scientific literature defines these terms as the agents of public administration, legislation, and the President of Hungary. As such, e-Administration in Hungary comprises the IT technologies and procedures of state administration (that is, the central and regional executive bodies of the government), and the administrative actors of the local self-governments. My goal is to describe this narrowlydefined type of e-Administration as it has been realized in Hungary so far.

\section{E-Government and E-Administration: Clarifying the Fundamental Concepts}

Legislative literature offers several definitions for e-Administration. The website of the Magyary Programme for example defines the concept as follows: "e-Administration is an extensive task, an aspiration in public administration development which aims to improve its work efficiency by utilizing the most suitable IT solutions." Ancsin, however, defines the goal of e-Administration as "the transformation of the internal and external contacts of the public sector via the modern technical means of infocommunications, and the transactions that can be realized by those". ${ }^{3}$ I myself consider the second definition as the definite one. e-Administration, in a wider sense, means the computerization of public administration, the digitalization of traditional office work to electronic solutions, the online availability of public administration services and electronic records, and the use of computerized administrative systems. Due to their specialized nature, the systems and records used in the specific administrative branches are subject to those specific parts of the administrative system. In this sense, e-Administration also comprises all specialized areas of administration where some (or all) activities are digitalized (such as hospital records, employee registration, electronic communication between the court and authorities, or the public procurement of administrative agencies). In a narrow sense, 
e-Administration means the computerization of public proceedings, along with their front office and back office connections.

We are living in the age of information society. Electronic procedures are becoming widespread, and take the lead against traditional, paper-based proceedings. As Szittner states, "the question is not whether computerization is needed; it is rather how it should be or should not be done". ${ }^{4}$ At the same time, Tózsa concludes that "the electronic and communication networks, which channel the new resource of information, inevitably enter the administration of public duties."

Electronic communication is present in almost all aspects and levels of life. IT systems are widely used not just by large companies, but by small and medium-size enterprises, as well. It is important to stress though, that there are still lots of problems to sort out in this area, so we are far from a full-fledged, actual e-Administration system at this time. Still, the topic is justified, and is worthy of research.

But what does e-Administration actually mean? No specific definitions are available, though its levels were tried to be classified multiple times. ${ }^{6}$

In my opinion, "electronic administration is neither equal to the automation of certain work processes, nor to the replacement of the human workforce with machines. [...] The term can be approached from a front office (client-side) and back office (authority-side) aspect as well: in this respect, it means providing new types of public services both for offices and clients, or at least facilitating to reach existing services via new methods. From the back office (or office) side, the state is able to coerce its subordinated organizations to switch over to these new methods, and can support this transformation and the development of the technical infrastructure via financial stimulations"?

In the EU, the digital and e-Administration services are measured by the following four indicators:

1. The e-Government User Indicator. This means the amount of administrative applications submitted electronically.

2. The presence of submitted intelligent e-Forms. This means the automatic loading of data available to authorities.

3. The complexity of public e-Services. This measures which and how many steps of public proceedings happen electronically.

4. The open data indicator.

Based on the above, Hungary achieved a score of $39 \%$, which earned her the $4^{\text {th }}$ place from the bottom on the list of EU countries, against the EU average of 55\%. ${ }^{8}$

\section{The Domestic Evolution of e-Administration}

The effort to digitalize various life situations, legal relations and services goes back almost two decades. While certain initiatives have been planned earlier than that," the first legal form of digitalization manifested only in 2003. ${ }^{10}$

The Közigazgatási hatósági eljárás és szolgáltatás általános szabályairól szóló 2004. évi CXL. törvény [Act CXL of 2004 on the General Procedural and Service Regulations of Public Administration Authorities] (hereinafter Ket.) contained regulations for the general 
procedures of public administration authorities (covering all branches of the administrative system). Originally, it covered the rules of main proceedings, legal remedies and execution - it was this framework, to which legislation added the regulations of e-Administration in 2004, concentrating mainly on the means of communication and the electronic availability of documents. In 2015, the Elektronikus ügyintézés és a bizalmi szolgáltatások általános szabályairól szóló 2015. évi CCXXII. törvény [Act CCXXII of 2015 on the General Rules for Electronic Administration and Trust Services] (hereinafter e-Administration Act) came into force, bringing fundamental changes in the area of e-Administration. As we will see, the process of e-Administration was unmatured at this time, both technically and also considering its legal status.

The e-Administration Act defines e-Administration as the electronic performance of administrative activities, or making declarations electronically. ${ }^{11}$ It does not specifically concentrate on the process of administration (generally mapping a procedure), as its regulations go beyond the public administration organizations (and this was not a goal with Ket. either). The past and current regulations both aim to establish the framework that would help realizing e-Administration: mosaic services available to clients and the authorities alike that would offer secure means of electronic communication for both sides. There is, however, another service related to e-Administration which provides its lifeline: the IT backbone (with its equipment pool and software) and its services related to the information society (such as websites, or the front and back offices of the administrative user interface). In this approach, e-Administration basically means two things: besides having the clients initiating electronic cases and possibly submitting (uploading) declarations, it could also stand for the proceedings and decision-making mechanism of the related authorities. Therefore, their work must also be supported by IT resources which - by means of a framework - also require legal regulations.

Putting e-Administration into a legal framework raised many issues in the past years, the best proof of which is the fact that its rules were constantly shifting within the legal system and regulations. When Ket. took effect, the possibilities of electronic administration significantly increased, as the act made it possible to practice certain administrative actions electronically, as well as let authorities inform clients on their decisions by electronic means. However, most of the local self-governments were unprepared for this channel of administration; therefore, in line with the regulations of Ket., ${ }^{12}$ most of them enacted local decrees that ruled out the possibility of handling any official matters via electronic means.

Legislation has established a central electronic service provider system, and as part of it, an $\ddot{u} g y f e ́ l k a p u$ [client access portal] as well, to which self-governments and other organizations could also connect. However, at the beginning, only about $1 \%$ of the selfgovernments connected to the client access portal voluntarily. To speed up their electronic integration and connection to the client access portal, legislation forced self-governments via a government decree ${ }^{13}$ to publish announcements electronically (via e-forms) on the client access portal. With this method, the state facilitated the creation of the technical background by legal means for the self-governments. ${ }^{14}$

In 2005, Ket. defined two means to initiate electronic administrative matters. The first method (the direct one) was the usage of high-security digital signatures, while the second 
one was letting clients send their applications through the client access portal of the central electronic service provider system.

When Ket. took effect, e-Administration received a separate article within the act with the details expanded in implementing regulations by the legislator. However, it soon became apparent that the regulations within Ket. were only enough for the computerisation of public proceedings; the framework would not be enough to regulate the numerous services of the central system developed by the government. Therefore, the concept (and its regulations) have been expanded, and eventually received separate legal regulation $s^{15}$ under the denomination of electronic public services, with its own implementing regulations. This central system became the sole channel of electronic client-authority and authorityauthority communications. The goal of this regulation was to eliminate specialized developments and custom solutions or services, and to centralize electronic administration. ${ }^{16}$

The Ekszt. unified the concepts related to electronic communication that occurred in the various sectoral legislation branches, and made electronic administration available as an electronic public utility to almost all actors of the economy and to civil organisations, as well.

The Ket. received further modifications ${ }^{17}$ in 2012, with the goal to replace the monopolistic solution (affecting both the delivery and development sides) with systems created from simpler, compatible and cooperative modules, ${ }^{18}$ that would consider the pangovernmental interests with much more emphasis.

This concept shift was also justified by the ever-changing needs of the population along with the constant technological improvements.

The core elements of this shift were the following:

1. Instead of using one government system, create several modules called szabályozott elektronikus ügyintézési szolgáltatások [regulated electronic administration services]; (hereinafter SZEÜSZ ${ }^{19}$ ), which can be developed and offered by market participants, as well. ${ }^{20}$

2. Develop a reporting and authorization system - the Elektronikus Ügyintézési Felügyelet [Electronic Administration Supervision] (hereinafter $E \ddot{U} F$ )

3. Create technology-neutral regulations.

The modification of Ket. in 2011 ceased the former centralized model, and started focusing on the regulation of the proceedings instead of the regulation of the technology used. It established a regulatory framework which allowed public administration the flexibility of using proven solutions developed by market participants. ${ }^{21}$

This same modification in 2011 also repealed the regulations of Ekszt. and the 2009. évi LII. törvény a hivatalos iratok elektronikus kézbesitéséröl és az elektronikus tértivevényröl [Act LII of 2009 on the Electronic Delivery of Official Documents and the Electronic Acknowledgment of Receipt] (hereinafter Hiektv.), placing the regulations of e-Administration in the Ket. again, within its separate section. Rather than focusing on a central system, the new wording defined regulated electronic services and service providers, though it also emphasized that electronic communication with clients and other organizations shall only be available via government communication services. ${ }^{22}$ Regarding 
the means of communication, the act also defined electronic channels as a valid, though non-written form of legal communication. ${ }^{23}$ The government appointed the Minister responsible for e-Administration with nation-wide competence as the supervisory authority of electronic administration. ${ }^{24}$

The Ket. effective until 2017 did not consider electronic administration procedures as separate proceedings (regulated under a separate title); it rather fit them within the framework of traditional procedures, by introducing a couple of specialties in its section of e-Administration (Section 10). The equality of electronic and paper-based administration methods was guaranteed by Section II/A (defining the rules of communication), and the declaration ${ }^{25}$ of equal probative values for electronic and paper-based documents.

By defining e-Administration as a means of communication, and establishing it as an accessible means of administration for clients, Ket. made electronic administration not just equal to traditional paper-based administration, but almost made it the primary means of proceedings. This was also supported by the main principles of speed, efficiency and cost effectiveness defined in the act. Exclusion of electronic means was only possible in unique cases, such as special legal regulations, the lack of technical conditions, ${ }^{26}$ or when e-Administration was incomprehensible for the specific scenario. The modifications of Ket., however, kept narrowing down these cases: eventually, only acts, government decrees issued in original legislative authority, and self-government decrees issued in self-governing authority matters could declare such scenarios.

2015 was another milestone in the history of Hungarian e-Administration. A new act took $\mathrm{effect}^{27}$ that repealed the special regulations concerning e-Administration and its public proceedings, and also returned to the 2009 model, establishing a unified framework for all electronic proceedings. This framework was the Egységes Digitális Ügyintézési Tér [Unified Electronic Administration Environment]. The major difference between the current regulation and the 2009 one is that while the legislation realized the necessity of a centralized model and extended the rules of e-Administration to every sphere, it still retained the independence of the SZEÜSZ modules (available to clients and authorities) for market participants. While the regulations defined in the act cover electronic administration matters beyond that of public administration, this study focuses solely on the rules of electronic public administration; hence it does not cover the new regulations of other areas (such as trial procedures).

The act essentially strived to regulate two major areas. The first of these was the extension of e-Administration to all administrative sectors. This endeavour encapsulated two important statements that I would like to cover here. On the one hand, the new regulations restrict the possibility of excluding e-Administration methods even more: it can be ruled now only via acts or government decrees. This basically means that selfgovernments can no longer exclude electronic methods in their administrative affairs: they must provide the necessary services somehow. On the other hand, the legislation attempts to "realize the necessary developments in a way that, on the one hand, the already existing systems could be used by all claimants without the necessity of substantially modifying said systems; and on the other hand, where such systems do not exist, they shall be deployed easily and with low costs". ${ }^{28}$ Unfortunately, the recently declared decree which defines the necessity of connecting to the self-government Application Service Provider (ASP) does 
not really follow the above principles, as it makes connection mandatory for two systems (taxes and economy), and also enforces data transmission towards data banks regardless of the type of connection used. Besides this, the application to connect to the ASP (Csatlakozási konstrukció az önkormányzati ASP rendszer országos kiterjesztésébez [Constructing Connection to the Nation-Wide Extension of the Self-Government ASP System] - PACSDOP-2.1.2-CCHOP-1629) provides pecuniary assistance only for those self-governments that choose complete connection (system connection) to the ASP. This effectively puts those self-governments at a disadvantage who stick to the old, proven systems, generating additional costs and extra development required for the connection.

Another aspiration of the act that deserves appreciation is that by targeting the realization of levels $4-5$ of the CLBPS recommendation, it tries directing all possible communications (client/consumer [hereinafter client] - authority/service provider [hereinafter authority] or authority/authority) to electronic channels. Besides this, it also observes the parameters (identification method, representation) provided by clients, the form of maintaining contact, and the means of administration, as well (such as administrative stipulations or personalized administrative interfaces). It only regulates the means of communication and the technical requirements of data transmission; it does not create any new legal titles for data handling.

In order to expand e-Administration and ensure a unified regulation, the act merges several other former acts (such as the Eat. ${ }^{30}$ and the Ioptv. ${ }^{31}$ ). With the further development of the system created for Ioptv., it becomes possible to regulate the flow of all electronically available data between organizations bound to electronic administration. The eventual goal is to let all information and data necessary for the information-technological cooperation be available for all cooperating organizations. This can be ensured by enforcing their obligation to supply information.

The second major area covered by the act is the field of e-identification and trust services, on the grounds of the related EU directive. ${ }^{32}$ This directive defines cooperative obligations for all member states regarding their e-identification systems. Its main principles are voluntary reporting and mutual acknowledgment: in other words, reporting the systems is optional, but in case a member reports its system, the rest of the member states must acknowledge it wherever it is used. ${ }^{33}$ Needless to say, the mutual knowledge, inspection and acceptance of the specific tools and identification solutions would be of great help for clients utilizing cross-country e-services. The eIDAS-regulation also covers e-Government solutions and all security solutions used by market participants, essentially breaking the absolutism of e-signatures. In Hungary, supervision is performed by the Nemzeti Médiaés Hirközlési Hatóság [National Media and Infocommunications Authority].

By defining and naming the concept of trust services, the eIDAS-regulation substantially restricts the scope for action of the Hungarian regulations. The goal with this was to increase trust in the e-communication methods, and to create a safe communication platform among member states.

Per the definition of eIDAS, trust services are electronic services usually provided for a compensation, and include the following: 
1. electronic signatures, electronic stamps or electronic timestamps, electronic delivery solutions for registered mail, and creating, verifying and authenticating certificates for the said services, or

2. creating, verifying and authenticating website-authenticator certificates, or

3. keeping electronic signatures, electronic stamps, or certificates related to the said services.

With eIDAS taking effect, the Eat. has been repealed. Since then, the $e$-Administration Act ensures that the obligations toward the EU are met.

The act also names several identification services provided by the government: these are the client access portal, the e-card, and partial code-based phone identification. All these services are built from a unified client registration register.

The new regulation also allows the identification of economic organizations via natural persons acting as their representatives, provided that these persons are identified, and their power of agency is verified. Moreover, if the power of agency results from certified public records or the administrative stipulations of the economic organization, further verification of the power of agency is neither required, nor demandable.

In case it is required for electronic administration matters bound to identification, foreign clients (such as persons unregistered due to lack of Hungarian residence) can voluntarily register to the database of foreigners applying for e-Administration. However, they are, of course, entitled to utilize such services even if they decline registration, as long as they use the solutions defined in eIDAS. ${ }^{34}$

The freedom of service providing and the simplification of procedures in e-Administration were first defined as expectations in the Service Directive ${ }^{35}$ of the EU; the Hungarian Government implemented these expectations with $A$ szolgáltatási tevékenység megkezdésének és folytatásának általános szabályairól szóló 2009. évi LXXXV. törvény [Act LXXVI of 2009 on the General Rules of Commencement and Pursuit of Service Activities]. The guarantee of the possibility of single-windowed administration (or in other words, the Points of Single Contact, or PSCs) was also defined here the first time, which was eventually realized in Hungary with the so-called kormányablakok [government windows]. The eugo.gov.hu website was launched in effect to the Directive, and aims to provide information for foreigners, mostly for business activities; however, it unfortunately provides no e-administration services. Access to the client access portal was supposed to be provided by magyarorszag.hu for foreigners; however, the above-mentioned website provides no means to login to it, while magyarorszag.hu lacks any kind of foreignlanguage information.

\section{The Means of Electronic Communication in Public Administration Proceedings}

The legal regulation differentiates between the type and means of communication. As mentioned earlier, e-communication can be basically performed in every form (both oral and written), because due to the convergence, it is now possible to contact authorities or 
service providers through almost any kind of IT device. Ket. and the e-Administration Act made this possible with various legal consequences.

Until 2017, the means of e-communication were listed by Az elektronikus ügyintézés részletes szabályairól szóló 85/2012. (IV. 21.) Korm. rendelet [Government Decree 85/2012 (IV. 21.) on the Detailed Provisions Regarding Electronic Administration]. ${ }^{36}$ One of the key properties of its regulations is that it provides relatively large freedom in the means of communication, and it does not enforce the usage of any specific system. That said, it should be noted that three out of the five means listed in the decree are SZEÜSZs provided by the state on an obligatory basis.

Legislation defined no detailed rules regarding mailing and document uploads, though the explicit identification of senders is unavailable in these cases; hence they can be used only with limitations. ${ }^{37}$

The secure e-delivery service has been developed by the Magyar Posta Zrt. [Hungarian Postal Service Inc.]. The legal consequences of this service are the same as the traditional notice of receipt, thus it is suitable for the delivery of official statements of decisions, as well.

The administrative stipulations are basically the representations of personalization. ${ }^{38}$ They are used to authorize proxies, define the type of identification to use (client access portal, elevated-security access site, phone identification), list contact information, enable periodic notifications on the selected electronic activities, and also to enable or block the selected means of communication.

Regarding identification, Hungary chose the knowledge-based identification of providing a password-based login routine built in the client access portal for its citizens. ${ }^{39}$ Recent developments aimed to expand the group of legal entities (economic organizations, non-administrative organizations, foreign individuals) who can use the client access portal (on client-side) or the official access portal for organizations, and also to offer means for multi-factor authentication (MFA) as well (via phone code). For the sole role of identification, a new SZEÜSZ, the központi azonositási ügynök [Central Identification Agent] (hereinafter KAÜ) was created. These developments of course can use some improvements: for example, after logging in to the government portal, users need to re-log in on kau.gov.hu.

According to the currently existing legislation, ${ }^{40}$ clients may utilize electronic identification services provided by ID cards containing storage elements (hereinafter e-ID card), the client access portal, and partial code-based phone identification as electronic identification services provided by the government on an obligatory basis. The records of the applicants using any of these services are kept in the Központi Ügyfél-regisztrációs Nyilvántartás [Central Client Registration Register] (hereinafter KÜNY).

Depending on the chosen method, clients may identify themselves as follows:

1. In case of using electronic identification services provided by e-ID card, by scanning the identification data stored on the card's storage element, and using the PIN code of the permanent ID card.

2. In case of partial code-based phone identification, by providing the user identification and password. 
3. In case of using the client access portal, by logging in with the username and password, and using a secondary authentication method.

In case of using an ID card issued since January 1, 2016, clients may request access to the client access portal electronically, as well. ${ }^{41}$

Regarding the KÜNY, the government elected the following organizations, persons, and tools as its registration authorities: the capital and county government offices, the district-level offices of said government offices, the Minister responsible for e-Government services, the Nemzeti Adó- és Vámbivatal [National Tax and Customs Administration], the Magyar Posta Zrt., the embassies and consulates of Hungary, ${ }^{42}$ and the e-ID cards issued since January 1, 2016.

Electronic forms formerly authenticated by e-signatures are gradually falling into the background. Electronic ID cards now contain built-in e-signature and fingerprint information as well, though their use potential is currently unknown.

Also, in the age of smartphones, clients should be able to contact the authorities not just in person or online, but by phone, as well. This could be realized by the utilization of the e-identification functions of e-ID cards.

\section{Interoperability in Practice}

The need for cooperation, communication and data exchange among the IT systems have appeared in EU-level expectations already back in the 2000s, ${ }^{43}$ due to the fact that administration usually involves the usage of multiple specialized systems even when handling a single case. To achieve actual and complete e-Administration, these systems must be able to forward data to each other, and they should possess no parallel databases, as that would often result in storing conflicting data for the same client.

Interoperability can be defined on multiple levels. ${ }^{44}$ The optimal case is when it is realized on all administrative levels. In a political sense, interoperability means the willingness of decision makers to establish cooperation among the various organizations and systems. By 2016, this political interoperability certainly existed. On the organizational level, interoperability is ensured ${ }^{45}$ by the establishment of county-level government offices, the creation of districts, the transfer of state administration duties from self-governments, the integration of special-duty organizations and tasks into county-level government offices and ministries, and the creation of the single-windowed PSCs. ${ }^{46}$

From the technical side, the European Committee created the European Interoperability Framework (EIF) of the European (cross-border) public services, and the European Interoperability Strategy (EIS). The framework is based on the agreement of the organizations aiming to cooperate with each other, and defines the public administration and private sector expectations toward public services, thereby creating the conceptional model of public services, and the levels of interoperability required for its realization. ${ }^{47}$ This guarantees the common definition of interoperability on EU-level. The strategy also provides guidance and sets priorities among the European public administration systems regarding the cross-country and cross-specialization interactions, and the activities related 
to the improvement of information exchange and cooperation during the establishment of European public services. ${ }^{48}$

In Hungary, the first regulation aiming to establish interoperability was in effect from January 2015, and was the Az állami és önkormányzati nyilvántartások együttmüködésének általános szabályairól szóló 2013. évi CCXX. törvény [Act CCXX of 2013 on the General Rules of Collaboration Between State and Self-Government Records ${ }^{49}$ ] that enforced the cooperation between the records of the various authorities.

This regulation enforced only data connection: it did not define the means of how to record data, and what format to use. It primarily aimed to establish a data connection service, so that there would be constant communication between the various registers and records, thereby the latest information would always be available during queries, regardless of the authority where the query is made. This data connection service is a service whereby registers allow other registers to transfer data via manual or automatic data transfer, as defined in the act. The registry containing the primary data is obliged to provide information, while the registry handling the derived data is obliged to receive it. The job of the government then was to clearly define what primary and derived data means in such cases.

To establish the proper proceedings, the act ordered the affected registers to create data connection service rules, and to sign data connection service agreements between each other.

It also charged a separate organization with the supervision of the area, and assigned a central address register to ensure unified address handling. Most of the regulations of the act took effect in July 1, 2015, though the service providers received substantial days of grace as well: they are obliged to meet the regulations of the act by the first day of the $30^{\text {th }}$ month following the act's entry into force (which means January 1, 2018).

Another expectation of the act was to make the already developed e-Administration systems and related specialized systems connectable, and to make them able to communicate and permeate each other. After all, e-Administration only makes sense if these conditions are met: only in this case can procedures be sped up, avoiding the concurrency and time-spending of paper-based traditional and electronic procedures.

Since January 1, 2017, the rules of interoperability are also part of the $e$-Administration Act. The cooperation is essentially defined on organizational, technical and semantical levels as well, as electronic data transfer among the various authorities have profound effects: their systems communicate with each other and interpret the received data, which results in better cooperation and more efficient work among the affected authorities. The act also restricts the means of contact: it can only occur either via delivery to an address in use for secure electronic communication, or by utilizing the file transfer service available between filing systems.

In light of the above changes it can be ascertained that the legal part of interoperability (along with its semantic part, due to the basic concepts laid down in the regulations) is properly regulated. Now, the regulations must be put into practice. After all, interoperability only exists if a government window offers a single solution to everyday situations. Once we are not directed to five different locations for five different certificates (despite attending business with a single authority), are not forced to visit the office a second time with 
a proof of receipt, and are not instructed to wait for days to receive an official acknowledgment for a piece of data which can otherwise be queried from a database, only then we can state that interoperability has been put in practice.

\section{E-Administration - Is it Still the Future?}

Years ago, regarding the future of e-Administration, I wrote the following: "Although there are sporadic attempts to expand e-Administration, for example EU subsidies like the Széchenyi 2020 KÖFOP, it is clear that to achieve this, measures must be taken on a central level. It is simply not enough to introduce sparse adjustments in the administrative subsystem of self-governments (handling most of the state-level and local cases affecting common citizens); instead, due to the lack of funds and the appearing resistance, a standard, unified, and accepted government software is needed, that would be available to all selfgovernments - similarly to the specialized systems, like ONKA or ASZA. The emphasis should be, on the one hand, on its state-level development and free availability, and on the other hand, on its mandatory usage." This aspiration now seems to come to fruition with the ASP-project of self-governments, which is already enforced legally by the Mötv. ${ }^{50}$ Hopefully, the provided modules, special systems, and the legislative-political intentions are indeed aimed to standardize administrative work, and to increase the efficiency and quality of public administration on the self-government level, instead of trying to achieve a greater level of control.

Another note of mine was made regarding document identification: "Its legislative background is substantially detailed, but it is missing the development and standardization of a unified system on the back office (authority) side, just like its nation-wide introduction (both on first- and second degrees for all administrative cases). This would require not just the technical development of an IT framework, but also the harmonization of IT, legal and organizational requirements; in other words, the creation of a knowledge-based workflow system, which would break down processes to individual steps, would also provide legal help and form templates for each step of the specific procedure, and would be flexible enough to immediately react to additional steps added any time to the procedure." Besides, it could handle the administrative and internal procedural deadlines, it would indicate omissions to the superior authorities or employers, and would always indicate the changes and availability of the documents related to the procedure. The system is also expected to connect specialized subsystems, ensure permeability, and eliminate the parallelism of paper-based traditional and electronic procedures.

It would be a huge improvement if the work of administrators could be proven not just by written documents, but the whole procedure would be mapped and stored electronically, and therefore could be checked up anytime, producing evidence when needed.

The Government itself also admits that "many times, the emphasis on the client-driven approach remained a mere buzzword, because in spite of the developments in legal regulations (for example having Ket. stipulating that clients cannot be asked to provide 
data which is otherwise available in the records of other authorities), no good progress was made in general in the area". ${ }^{51}$

Based on the Nemzeti Infokommunikációs Stratégia [National Infocommunications Strategy], we would be able to administrate everything electronically by 2020 with a guaranteed bandwidth of $30 \mathrm{Mbps}$, and with a connection of $100 \mathrm{Mbps}$ being available to at least $50 \%$ of the households. The strategy also aims to realize complete interoperability between databases by 2020, and to have central public administration institutions handle $80 \%$ of their processes via paperless, electronic means. ${ }^{52}$

Based on an EU survey, Hungary is the $4^{\text {th }}$ worst performer when it comes to electronic public services, positioned far from the EU average. ${ }^{33}$ We own the penultimate position in the eGov-indicator of client-drivenness, and are $3^{\text {rd }}$ from the bottom of the list on the eGov-indicator of transparency. ${ }^{54}$

The basics of the current regulation are fine. On the one hand, the centralization (which already appears in numerous aspects ${ }^{55}$ of e-Administration) is required; on the other hand, making the various functions and services available on the market to ensure the more efficient and complete service of clients is certainly a good direction. e-Administration requires standardization and central decision-making, due to the complexity of its technical background, to ensure the interoperability of its systems, and eventually to achieve its general availability. What is required is a standard, general and unified software/system accepted (and made mandatory) on a state level, which would be then made available to all administrative organizations, or at least to all organizations within the various administrative sub-systems. So far, regulation only covered the entry points used by the clients and authorities (the client access portal and office access portal, respectively - and which should be clarified further). However, to ensure the vitality of the area, the two entry points should be connected, and besides guaranteeing a secure backbone network, an IT, administrative and legal application is also required that would provide a complete workflow ${ }^{56}$ for the entire administrative procedure, handling both front and back office processes from submitting a form through conveying decisions to providing electronic payment methods, as well.

The above statement is not completely true nowadays though, as the developments are already underway, and the organizational integration of regional-level state administration leads to the need of establishing permeability among the various specialized systems. At the same time, on the level of self-governments, the deployment of the ASP also serves the same goal of standardization and unification. The procedure thus started - we are now looking forward to its continuation.

My study focused primarily on the legal and administrative aspects of the need for e-Administration and electronic proceedings. That said, the topic could also be investigated from an IT perspective, focusing on topics such as the need for network developments, increasing bandwidth, establishing knowledge centres, and increasing interoperability in cross-authority communication.

The unstoppable expansion of electronic administration in the public and private sectors also justifies the effort to create a unified framework for e-Administration, regardless of the actors of e-communication (such as administrative organizations, courts, or public service providers). Challenges of the upcoming years in this respect include the 
creation and maintenance of a cross-border digital infrastructure, the expansion of electronic public procurement, and the support of using contractual records. The EU aims to let enterprises run on public procurement tenders electronically anywhere in the EU by 2018, and to make e-billing an accepted form of billing by every public administration system by 2019. The Committee also plans further actions regarding e-identification to speed up its cross-border and cross-specialization usage.

We must admit that Hungary is lagging a decade behind the EU when it comes to e-Administration: after all, while the EU took concrete steps to develop the strategy of e-Administration in the 1990s, the first initiatives in Hungary were only made at the beginning of the 2000s. We also could not meet the related deadlines of the EU, such as the eEurope 2005 or the CLPBS recommendations. The idea of using integrated, interoperable systems and services is good, but we should not forget that there are several countries which use such services for years now.

I can only hope that the next five years will bring substantial changes in this field; however, launching the new developments, along with their reconciliation and alignment to practical needs will not occur without problems - just like the elimination of the resistance against the new and unknown. 


\section{References}

1 The work was created under the priority project PACSDOP-2.1.2-CCHOP-15-2016-00001 entitled "Public Service Development Establishing Good Governance" in cooperation with the National University of Public Service and the "DE-ÁJK Governance Resource Management Research Group" of the University of Debrecen. For the description of the underlying concepts, see: Tamás M. Horváth, Ildikó Bartha, Az ágazati közszolgáltatások rendszertanáról [The Theoretical System of Public Service Sectors], 25-37, in Tamás M. Horváth, Ildikó Bartha (eds.), Közszolgáltatások megszervezése és politikái [The Organization and Sectors of Public Services] (Budapest, Dialóg Campus, 2016).

2 http://magyaryprogram.kormany.hu/admin/download/d/2c/40000/Magyary\%20kozig\%20fejlesztesi\% 20program\%202012\%20A4.pdf (accessed 02 January 2015).

3 László Ancsin, Az e-közigazgatás [The e-Administration], 37, in Új Magyar Közigazgatás, vol. 5, no. 5 (2012).

4 Károly Szittner, Út az elektronikus közigazgatáshoz [The Way to Electronic Administration], 5, in Új Magyar Közigazgatás, vol. 2, no. 4 (2009).

5 István Tózsa, Az elektronikus közigazgatás helyzete [The Situation of Electronic Administration], 2, in Új Magyar Közigazgatás, vol. 5, no. 5 (2012).

6 Lasse Berntzen, Morten Goodwin Olsen, Benchmarking e-Government - A Comparative Review of Three International Benchmarking Studies, 77-82, (Cancun, Third International Conference on Digital Society, 2009); Balázs Benjámin Budai, A közigazgatás és az elektronikus közigazgatási fejlesztések hatékonyságának mérése napjainkban [The Measuring of Effectivity of Administration and Electronic Administration Nowadays], 13-29, in Új Magyar Közigazgatás, vol. 5, no. 5 (2012). https://doi.org/10.1109/ICDS.2009.55

7 Bernadett Veszprémi, A közigazgatás döntései, a közigazgatási aktustan [Administrative Decisions, Study of Administrative Acts], 175-176, in Zsuzsanna Árva, István Balázs, Attila Barta, Bernadett Veszprémi, Közigazgatás-elmélet [Theory of Administration] (Debrecen, Debreceni Egyetemi Kiadó, 2012).

8 European Commission Digital Agenda Scoreboard, https://ec.europa.eu/digital-agenda/news_redirect/ 16475 (accessed 31 December 2016).

9 Nemzeti Informatikai Stratégia [National IT Strategy] (1995), Magyar válasz az Információs Társadalom kibivasaira [Hungarian Answer to the Challenges of the Information Society] (1999), Tézisek az Információs Társadalomról [Theses on the Information Society] (2000), Magyar Informatikai Charta [Hungarian IT Charta] (2000), Nemzeti Információs Társadalom Stratégia [National Information Society Strategy] (2001).

10 1126/2003. (XII. 12.) Korm. határozat a Magyar Információs Társadalom Stratégiáról és annak végrehajtásáról [Government Resolution No. 1126/2003 (XII. 12) on the Hungarian Information Society Strategy (MITS) and its Execution].

11 e-Administration Act, $\$ 8$, article (1).

12 Based on the wording of Ket. back in 2005, acts, government decrees and self-government decrees may rule out the administration of specific cases electronically.

13 225/2008. (IX. 9.) Korm. rendelet a termöföldre vonatkozó elövásárlási és elöhaszonbérleti jog gyakorlásának részletes szabályairól szóló 16/2002. (II. 18.) Korm. rendelet módositásáról [Government Decree No. 225/2008 (IX. 9) on the Modifications of Government Decree No. 16/2002 (II. 18) on the Detailed Regulations of Practicing Pre-Emption and Pre-Leasing of Agricultural Land] $₫ 2$, www.kozlonyok.hu/ nkonline/MKPDF/hiteles/mk08130.pdf (accessed 21 August 2014).

14 Repealed on 30 March 2009.

15 Az elektronikus közszolgáltatásról szóló 2009. évi LX. törvény [Act LX of 2009 on Electronic Public Service] (hereinafter Ekszt).

16 http://magyaryprogram.kormany.hu/download/b/cd/70000/A_jogszabalyi_keretek_osszefoglalasa_Ekozig_projektek.pdf (accessed 02 December 2014). 
17 A közigazgatási hatósági eljárás és szolgáltatás általános szabályairól szóló 2004. évi CXL. törvény és egyes kapcsolódó törvények, valamint a miniszteri hatósági hatáskörök felülvizsgálatával összefüggö egyes törvények módositásáról szóló 2011. évi CLXXIV. törvény [Act CLXXIV of 2011 on the Modification of Act CXL of 2004 on the Procedural and Service Regulations of Public Administration Authorities, Related Acts, and Acts Related to the Revision of the Official Authorities of Ministers], http://njt.hu/cgi_bin/njt_doc. cgi ?docid $=139785.210265$ (accessed 20 August 2014).

18 http://magyaryprogram.kormany.hu/download/b/cd/70000/A_jogszabalyi_keretek_osszefoglalasa_Ekozig_projektek.pdf (accessed 01 December 2014).

19 Electronic services whose contents and terms of services (that is, being bound to notice or permission) are defined by acts or government decrees. Some of these services are bound to be provided by the government (that is, the organizations listed in the related government decrees).

20 There are several agents who can be considered SZEÜSZ providers. Firstly, authorities who provide regulated electronic administration services for their clients or for their own inner administration. Secondly, authorities who provide such services for other authorities, as well. And finally, legal entities without authority status who provide regulated electronic administration services for clients and authorities, either for a fee, or free of charge.

21 http://magyaryprogram.kormany.hu/download/b/cd/70000/A_jogszabalyi_keretek_osszefoglalasa_Ekozig_projektek.pdf (accessed 02 December 2014).

22 Ket. $\$ 160$, article (3). Based on wording effective until 31 December 2016.

23 Ket. $\$ 28 /$ B, article (5). Based on wording effective until 31 December 2016.

$24 \$ 2$ of Egyes, az elektronikus ügyintézéshez kapcsolódó szervezetek kijelöléséröl szóló 84/2012. (IV.21.) Korm. rendelet [Gov. Decree No. 84/2012 (IV.21) on the Appointment of Certain Organisations Related to Electronic Administration].

25 Ket. $\$ 160$, article (4). Based on wording effective until 31 December 2016.

26 See articles (1) and (5) of Ket. \$28/B. Based on wording effective until 31 December 2016.

27 The e-Administration Act.

28 www.parlament.hu/irom40/07392/07392.pdf (accessed 12 July 2016).

29 https://www.palyazat.gov.hu/kfop-121-vekop-16-csatlakoztatsi-konstrukci-az-nkormnyzati-asp-rendszerorszgos-kiterjesztshez (accessed 01 March 2017).

30 Az elektronikus aláirásról szóló 2011. évi XXXV. törvény [Act XXXV of 2011 on Electronic Signatures] (hereinafter Eat.)

$31 \mathrm{Az}$ állami és önkormányzati nyilvántartások együttmúködésének általános szabályairól szóló 2013. évi CCXX. törvény [Act CCXX of 2013 on the General Rules of Cooperation Between State and SelfGovernment Records] (hereinafter Ioptv.)

32 Regulation (EU) No. 910/2014 of the European Parliament and of the Council of 23 July 2014 on Electronic Identification and Trust Services for Electronic Transactions in the Internal Market and Repealing Directive No. 1999/93/EC (hereinafter eIDAS-regulation).

33 Obligatory from 2018.

34 www.parlament.hu/irom40/07392/07392.pdf (accessed 12 July 2016).

35 Directive 2006/123/EC of the European Parliament and of the Council of 12 December 2006 on Services in the Internal Market, http://eur-lex.europa.eu/legal-content/HU/TXT/?uri=celex:32006L0123 (accessed 01 March 2017).

$36 \S 7$, article (1): "Where the possibility of electronic communication is provided, the usage of the means of communication is provided by the authority, clients without administrative stipulations may submit applications within the scope of the electronic communication means as follows:

a) by utilizing secure electronic delivery services,

b) within the scope of the law, by the support service of submitting an ÁNYK (Általános Nyomtatványkitöltö [General Form Filler App]) form in accordance with the specific provisions,

c) via electronic mail with the conditions observed in article (2),

d) by uploading documents through the internet-based interface provided by the authority, or, 
e) by utilizing further means of contact enabled by the administrative stipulations of the clients.", http:// njt.hu/cgi_bin/njt_doc.cgi?docid=148205.322472 (accessed 12 July 2016).

37 In these cases, identification and authentication can be performed by e-signature.

38 https://rendelkezes.kekkh.gov.hu/rny-public/ (accessed 01 March 2017).

39 www.magyarorszag.hu (accessed 01 March 2017). It should also be mentioned that e-signatures can also be used for authentication and identification purposes. Still, the government aimed to realize e-Administration primarily within the framework of a central system.

$40 \mathrm{Az}$ elektronikus ügyintézés részletszabályairól szóló 451/2016. (XII.19.) Korm. rendelet [Government Decree No. 451/2016 (XII. 19) on the Detailed Rules of Electronic Administration] (hereinafter e-Administration Decree)

$41 \S 35$, articles (1)-(2) of the e-Administration Act. Also, see $₫ 71$, article (1) and $₫ 72$, article (2) of the e-Administration Decree.

42 In case of applying for the new e-ID card, the registration application can be submitted only where applications can be submitted for permanent ID cards, as per the 414/2015. (XII. 23.) Korm. rendelet a személyazonositó igazolvány kiadása és az egységes arcképmás- és aláirás-felvételezés szabályairól [Government Decree No. 414/2015 on Issuing Identity Cards and on Regulations of Unified Registering of Facial Images and Signatures].

43 COM (2006) 173 - i2010 eGovernment Action Plan on Accelerating eGovernment in Europe for the Benefit of All. Decision 2004/387/EC of the European Parliament and of the Council of 21 April 2004 on the Interoperable Delivery of Pan-European eGovernment Services to Public Administrations, Businesses and Citizens (IDABC), (HL L 181, 18 May 2004, p. 25). 1639/2006/EC - Decision of the European Parliament and of the Council of 24 October 2006 Establishing a Competitiveness and Innovation Framework Programme (HL L 310, 09 November 2006, p. 15). Decision No. 922/2009/EC of the European Parliament and of the Council of 16 September 2009 on Interoperability Solutions for European Public Administrations (ISA) (HL L 206, 10 March 2009, p. 11).

44 Módszertani útmutató az interoperabilitás tervezésének támogatására [Methodological Guide for the Support of Planning Interoperability], 10 (Budapest, Miniszterelnöki Hivatal [Office of the Prime Minister], 2008); COM (2010) 744: Communication from the Commission to the European Parliament, the Council, the European Economic and Social Committee and the Committee of the Regions Towards Interoperability for European Public Services, 3-4 (Brusells, 2010), www.europarl.europa.eu/RegData/ docs_autres_institutions/commission_europeenne/com/2010/0744/COM_COM(2010) 0744_HU.pdf (accessed 26 July 2016).

45 In line with the regulations of $A$ fóvaarosi és megyei kormányhivatalokról, valamint a fóvaarosi és megyei kormányhivatalok kialakitásával és a területi integrációval összefüggö törvénymódositásokról szóló 2010. évi CXXVI. törvény [Act CXXVI of 2010 on Metropolitan and County Government Offices, and on the Amendments in Connection with the Formation and Regional Integration of the Metropolitan and County Government Offices], starting from January 1, 2011, county and capital government offices became the regional general-authority administrative organizations of the government. Starting from 2011, regional special-duty authorities were gradually merged into county-level government offices, first generating a shared (organizational and specialized) management, and then numerous major departments and departments within the offices, as they lost their independence. District management has been introduced in 2013 by $A$ járások kialakitásáról, valamint egyes ezzel összefüggó törvények módositásáról szóló 2012. évi XCIII. törvény [Act XCIII of 2012 on the Formation of Districts and the Amendment of Certain Associated Statutes], as an administrative unit below the counties, belonging to the organization of countylevel government offices. Following the inception of the districts, administrative duties formerly belonging to the self-governments (including those of the registrars, administrators and mayors) were gradually transferred/returned to the district offices.

46 Based on Directive 2006/123/EC of the European Parliament and of the Council of 12 December 2006 on Services in the Internal Market. In Hungary, it was realized under the name of kormányablak [government window]. 
47 Even this framework already builds the European public services as modules, which enables connecting the various services.

48 COM (2010) 744: Communication from the Commission to the European Parliament, the Council, the European Economic and Social Committee and the Committee of the Regions Towards Interoperability for European Public Services. Final text, 8.

49 http://njt.hu/cgi_bin/njt_doc.cgi?docid=165627.254004 (accessed 01 January 2015).

50 2011. évi CLXXXIX. törvény Magyarország helyi önkormányzatairól [Act CLXXXIX of 2011 on the Local Governments of Hungary].

51 E-közigazgatási keretrendszer koncepció [e-Administration Framework Concept], Belügyminisztérium [Ministry of the Interior], 29 April 2015, www.kormany.hu/download/0/05/50000/E-k\%C3\% B6zigazgat\% C3\%A1si_keretrendszer_koncepci\%C3\%B3.pdf (accessed 26 July 2016).

52 http://2010-2014.kormany.hu/download/b/fd/21000/Nemzeti\%20Infokommunik\%C3\%A1ci\%C3\%B3s\%20Strat\%C3\%A9gia\%202014-2020.pdf, 81 (accessed 21 March 2017).

53 https://ec.europa.eu/digital-single-market/en/scoreboard/hungary\#5-digital-public-services (accessed 26 July 2016). For example, in 2016, the amount of personalization in Hungary (that is, automatically filling forms with data available to the system or the administrative organization) was $19 \%$, compared to the EU average of $49 \%$.

54 http://digital-agenda-data.eu/charts/analyse-one-indicator-and-compare-countries/ (accessed 09 December 2014).

55 Such as in the NTG and specified SZEÜSZ providers. Examples of technical interoperability include the self-government ASPs and the Ioptv. Regarding organizational interoperability, examples include the integrated development of government offices and government windows (kormányablakok), along with the concentration of tasks.

56 "Breaking down administration to knowledge-based, process-driven steps. e-Administration does not merely mean the development of a framework: it rather means the harmonization of IT, legal, and organizational conditions, resulting in a knowledge-based workflow system offering both front office and back office services. Public administration proceedings can be divided to steps and sub-steps that can be modelled. There are elements which can be inserted into this flowchart, and there are also elements which may appear anytime during the procedure, and thus need to be handled as independent elements when developing an electronic system.” Zsuzsanna Árva, István Balázs, Attila Barta, Bernadett Veszprémi, Közigazgatás-elmélet [Theory of Administration], 180-181 (Debrecen, Debreceni Egyetemi Kiadó, 2012). 